\title{
The Impact of Staff Competence on Procurement Performance In Public Procurement In Rwanda A case of Rwanda Public Procurement Authority
}

\section{Harriet MUTESI ${ }^{1}$ and Dr Ernest SAFARI ${ }^{2}$}

\author{
${ }^{1}$ School of Business, Mount Kenya University, \\ Kigali, Rwanda
}

${ }^{2}$ School of Procurement and Supply Chain Management, Mount Kenya University, Kigali, Rwanda

\begin{abstract}
This study determined impact of staff competency in executing procurement work. A descriptive research design was adopted using both qualitative and quantitative approaches. The target respondentswas125procurement staff. With a sample of the size $n=95$. A questionnaire and interview guide were used. Data analysis was done using statistical package for social sciences. Results indicated that research based on research objectives is that there is a significant relationship between staff
\end{abstract}

\section{Introduction}

Over the years, researchers has been identifying the perfect skills for purchasing professional and this led to the rapid changes in the purchasing environment (Carr\& Smeltzer, 2000). Procurement was not known in the past years but rather function like marketing were in existence (Jeppesen, 2010). The formal scope of activities of purchasing agents was extremely limited, and purchasing professionals were involved rather late into the purchasing process (Gul, 2010).

Public procurement in Rwanda dated back in 1959 and the country was using a Royal Decree of June 26 1959, from Belgium. In identifying the impact of staff competency in public procurement in Rwanda, the country aimed at achieving value for money.

It is the researcher's assumption that Rwanda Public procurement authority needs to solve the risingchallenges in procurement service by:stablishing code of conducts in procurement system in Rwanda competences and procurement performance at Rwanda Public Procurement Authority as indicated by coefficient of 0.350 with a $\mathrm{R}$ square of 0.059 which is positive.Results demonstrated that coefficient for each independent variable were zero. This meant that all independent variables influenced the dependent variable.

Keywords: impact of staff competency in Rwanda Public Procurement Authority

Empowering RPPA staff members with more knowledge and others skilled related procurement practices, establishing training abilities for RPPA staff members to ensure efficiency and effectiveness of tasks and responsibilities, and reducing unnecessary costs thus encouraging transparency and work towards qualitative product or services.

According to Mbae (2014), the impact of Staff competence on public procurement performance can be evaluated through education level, procurement knowledge specialization, professional experience and skills.

The productivity of staff regarding procurement performance is based on the level of education qualification. In relation to this, Muange (2013) said that the increment in staff motivation and standard performance is a result of having educated and qualified procurement staff.

The objectives of the paper are: 
(i) To identify the extent to which staff competence contribute to procurement performance in Rwanda public procurement authority.

(ii) To determine the role of problem solving and decision making on procurement.

\section{Review of Literature}

A study conducted on the Impact of staff competence in public procurement showed that RPPA maintain skilled staffs who are more competent in achieving the core performance. This was strongly agreed by $84.2 \%$ of respondents.According to Keeney (2007), Nuxoll (2006) and Nuxoll(2006), the staff competence goes with individual assigned responsibilities within productive industry.The organization having no staff competence and proper control is determined by illegal practices in procurement domain. The traditional way of procurement was considered to be unfair as it leads to theft.Therefore, it's relevant to use electronic procurement system and train staff to gain competence as well as capacity building (Siri ,2005) and ( Keeney,2007).

In Africa and other developing countries procurement was practiced as a result of combined efforts supported byorganizations like financing organizations such as world bank, international monetary funds and other private financial organizations including trade organization and procurement institutions(Agaba\& Shipman, 2007).

To ensure efficiency and effectiveness of financial management in public sector, there is need to conduct procurement.(Basheka\&Kabatereine, 2013). In the context of problem solving, scholars evidenced that solving a problem consists of having analytical skills by institution workers in different department to get things right in terms of duties and responsibilities. The problem solving in the workplace assist clients throughout assisting technical team achieve the institution goals and objectives (Banda, 2009). staff competency in public procurement helps to solve problems and this goes

\section{Materials and Methods}

As Creswell (2013) asserts that target population is described as a group of people, institutions, and things concerning what one wants to find a conclusion. The target population for this study was 125 staff from Rwanda Public Procurement Authority. Using Cooper \& Schindler, 2006, a sample size of respondents were.

Eq (1):

$n=\frac{N}{1+N^{*}(e) 2}$

When $\mathrm{n}$ is representing, sample size,

$\mathrm{N}$ for size ofentire population,

$\mathrm{e}=$ margin error.

\section{ISSN 2455-6378}

(iii) To determine the contribution of communication and organization skills on procurement performance at Rwanda public procurement authority

with qualification, skills and knowledge of staff to acquire quality goods or works at a right time, from the right suppliers and at a low price (Raymond, 2008).

Concerning decision making, involves analyzing different alternatives and arriving at the right decision making.It is about reaching at conclusion or decision on which can be implemented as solution of problem. In public procurement, the way management apply decision making determines the level or degree of the institution performance (Russell, 2004).

It is very crucial to measure procurement performance based on the right decision making and this helps to assess progress towards its predetermined objectives thus finding areas of strength and weakness and this determines future initiatives and performance improvement (Van , 2005).

With effective communication, most of institutions require standard procurement procedures to attain procurement performance. These procedures include use of open tendering competition to acquire competent supplier, contract negotiations and management mostly regarding contract amount (Ouma, 2014).

According to Basheka (2009), communication enrich the profession of procurement based on theoretical knowledge, consistent training and education, thus effective procurement requires professionals and trained staff if possible, recognized by procurement professional body. This will prevent illegal practices like corruption which affect procurement performance that are mainly caused by lack of procurement professionalism.

When this formula is applied to the above sample, $\mathrm{n}=\frac{\mathrm{N}}{\left(1+N\left(e^{2}\right)\right)}=n=\frac{125}{1+125(0.05)^{2}}=\frac{125}{1.3125}=$

95, the sample size is therefore, 95 staffs. respondents out of the 125-target population with $5 \%$ of sampling error.

The study used probability sampling technique known as stratified sampling technique as well as simple random sampling technique. When random sampling is used, each element in the study population has an equal chance of being selected or 
has probability of being selected. Simple random sampling was used on respondents in the RPPA to get the required size. To ensure inclusiveness, respondents was selected from all respondents.
Furthermore, the non-probability sampling technique known as purposive sampling was used to select key informants. Primary data was gathered using questionnaires and interview guide

\section{Results}

\section{1staff competency}

\begin{tabular}{|c|c|c|c|c|c|}
\hline Statement & $\begin{array}{l}\text { Strongly } \\
\text { Agree, } \\
\text { n(\%) }\end{array}$ & $\begin{array}{l}\text { Agree, } \\
\mathbf{n}(\%)\end{array}$ & $\begin{array}{l}\text { Disagree, } \\
\text { n(\%) }\end{array}$ & $\begin{array}{l}\text { Strongly } \\
\text { Disagree, } \\
\text { n(\%) }\end{array}$ & Neutral \\
\hline \multicolumn{6}{|l|}{$\begin{array}{l}\text { RPPA maintain skilled and competences of } \\
\text { staff in achieving a core performance }\end{array}$} \\
\hline & $80(84.2)$ & $15(15.8)$ & $0(0.0)$ & $0(0.0)$ & $0(0.0)$ \\
\hline $\begin{array}{l}\text { RPPA staff competences is measured in } \\
\text { terms of productivity and accomplishment of } \\
\text { institution objectives }\end{array}$ & $16(16.8)$ & $79(83.2)$ & $0(0.0)$ & $0(0.0)$ & $0(0.0)$ \\
\hline $\begin{array}{l}\text { Efficiency and effectiveness of staff } \\
\text { competences within RPPA helps to achieve } \\
\text { competitive advantage }\end{array}$ & $69(72.6)$ & $22(23.2)$ & $4(4.2)$ & $0(0.0)$ & $0(0.0)$ \\
\hline $\begin{array}{l}\text { Through skills and competences maintained } \\
\text { by RPPA staff members are able to bring } \\
\text { innovation in procurement }\end{array}$ & $58(61.1)$ & $34(35.8)$ & $0(0.0)$ & $0(0.0)$ & $3(3.2)$ \\
\hline
\end{tabular}

Research findings showed that RPPA maintain skilled staffs who are more competent in achieving the core performance. This was strongly agreed by $84.2 \%$ of respondents while $83.2 \%$ of respondents also agreed.

staff skills and competences is measured, research findings showed that within RPPA, the staff skills and competences are determined by productivity and

\begin{tabular}{|c|c|c|c|c|c|}
\hline Statement & $\begin{array}{l}\text { Strongly } \\
\text { Agree, } \\
\text { n(\%) }\end{array}$ & $\begin{array}{c}\text { Agree, } \\
\text { n(\%) }\end{array}$ & $\begin{array}{c}\text { Disagree, } \\
\text { n(\%) }\end{array}$ & $\begin{array}{l}\text { Strongly } \\
\text { Disagree, } \\
\text { n(\%) }\end{array}$ & Neutral \\
\hline $\begin{array}{l}\text { RPPA maintain skilled and experienced staff } \\
\text { to solve problem }\end{array}$ & $32(33.7)$ & $60(63.2)$ & $3(3.1)$ & $0(0.0)$ & $0(0.0)$ \\
\hline $\begin{array}{l}\text { RPPA offers additional skills or trainings to } \\
\text { staff members to be capable in solving } \\
\text { problem }\end{array}$ & $64(67.4)$ & $31(37.6)$ & $0(0.0)$ & $0(0.0)$ & $0(0.0)$ \\
\hline $\begin{array}{l}\text { Efficiency and effectiveness of problem } \\
\text { solving within RPPA helps in achieving the } \\
\text { procurement performance }\end{array}$ & $32(33.7)$ & $60(63.2)$ & $3(3.1)$ & $0(0.0)$ & $0(0.0)$ \\
\hline $\begin{array}{l}\text { Through skills and experience maintained by } \\
\text { RPPA staff members, decision making is } \\
\text { done accordingly }\end{array}$ & $37(38.9)$ & $58(61.1)$ & $0(0.0)$ & $0(0.0)$ & $0(0.0)$ \\
\hline $\begin{array}{l}\text { Efficiency and effectiveness of decision } \\
\text { making in RPPA helps in achieving } \\
\text { procurement performance }\end{array}$ & $55(57.9)$ & $35(36.8)$ & $5(5.3)$ & $0(0.0)$ & $0(0.0)$ \\
\hline
\end{tabular}

As indicated in Table 4.2, findings showed that RPPA maintain skilled and experienced staff to solve problem as ideally strongly agreed by $33.7 \%$ of surveyed respondents. Moreover, the information achievement in competitive environment. This was strongly agreed by $16.8 \%$ of surveyed respondents while $83.2 \%$ of respondents also agreed. Most of the assessed respondents confirmed that the staff skills and competences within RPPA positively contributed to the institution performance at the rate of $99 \%$.

\section{2problem solving and decision making}


this led the management in achieving the procurement performance. The results were strongly pointed by $38.9 \%$ of respondents whereas $61.1 \%$ of respondents also agreed on the same.

Efficiency and effectiveness of decision making by the management of RPPA has led to procurement performance as indicated by $57.9 \%$ of respondents and this has also agreed by $36.8 \%$ of surveyed respondents. Based on results collected in this research, the overall conclusion is that problem solving abilities within RPPA was due to different factors including skills of institution managers, experience of staff managers and commitment.

Table 4.3communication and organization skills

\begin{tabular}{|c|c|c|c|c|c|}
\hline Statement & $\begin{array}{c}\text { Strongly } \\
\text { Agree, } \\
\text { n(\%) }\end{array}$ & $\begin{array}{l}\text { Agree, } \\
\text { n(\%) }\end{array}$ & $\begin{array}{l}\text { Disagree, } \\
\quad \mathbf{n}(\%)\end{array}$ & $\begin{array}{l}\text { Strongly } \\
\text { Disagree, } \\
\text { n(\%) }\end{array}$ & Neutral \\
\hline $\begin{array}{l}\text { There is effective communication among } \\
\text { staff members of RPPA }\end{array}$ & $76(80.0)$ & $19(20.0)$ & $0(0.0)$ & $0(0.0)$ & $0(0.0)$ \\
\hline $\begin{array}{l}\text { Effective communication among staff } \\
\text { members of RPPA helps in achieving } \\
\text { procurement performance }\end{array}$ & $62(65.3)$ & $33(34.7)$ & $0(0.0)$ & $0(0.0)$ & $0(0.0)$ \\
\hline $\begin{array}{l}\text { Having both technical, interpersonal, } \\
\text { communication and organization skills } \\
\text { within RPPA helps in achieving procurement } \\
\text { performance }\end{array}$ & $68(71.6)$ & $27(28.4)$ & $0(0.0)$ & $0(0.0)$ & $0(0.0)$ \\
\hline $\begin{array}{l}\text { The management of RPPA is well structured } \\
\text { and organized which led to its procurement } \\
\text { performance. }\end{array}$ & $57(60.0)$ & $34(35.8)$ & $4(4.2)$ & $0(0.0)$ & $0(0.0)$ \\
\hline $\begin{array}{l}\text { Having organization skills within } \\
\text { management of RPPA, duties and } \\
\text { responsibilities are accomplished. }\end{array}$ & $80(84.2)$ & $12(12.6)$ & $3(3.2)$ & $0(0.0)$ & $0(0.0)$ \\
\hline $\begin{array}{l}\text { Results showed that } 80.0 \% \text { strongly ag } \\
\text { effective communication among staff me } \\
\text { RPPA has contributed to procurement perf } \\
\text { This was also agreed by } 20.0 \% \text { of } \\
\text { respondents. In this research project, resear } \\
\text { interested in knowing if effective comm } \\
\text { among staff members of RPPA helped in } \\
\text { the procurement performance. researc } \\
\text { interested in knowing whether the manag } \\
\text { RPPA is well structured and organized to ac } \\
\text { procurement performance. The research }\end{array}$ & $\begin{array}{l}\text { eed that } \\
\text { nbers of } \\
\text { ormance. } \\
\text { surveyed } \\
\text { cher was } \\
\text { inication } \\
\text { chieving } \\
\text { er was } \\
\text { ment of } \\
\text { hieve the } \\
\text { findings }\end{array}$ & $\begin{array}{l}\text { revealed tha } \\
\text { RPPA is ach } \\
\text { structure } \\
\text { performance } \\
35.8 \% \text { agre } \\
\text { showed that } \\
\text { of RPPA, } \\
\text { accomplishec } \\
\text { institution p } \\
\text { agreed by } 84 \\
\text { surveyed }\end{array}$ & $\begin{array}{l}\text { the achiever } \\
\text { ved througho } \\
\text { ich contrib } \\
\text { ais was conf } \\
\text { l. As indic } \\
\text { rganization s } \\
\text { duties anc } \\
\text { overtime } \\
\text { formance. T } \\
\% \text { of responc } \\
\text { respondent }\end{array}$ & $\begin{array}{l}\text { hent or perfo } \\
\text { ut good organ } \\
\text { uted to } 0 \\
\text { rmed by } 60.0 \\
\text { ated, researc } \\
\text { kills within } \mathrm{m} \\
\text { responsibi } \\
\text { nd this ind } \\
\text { e results we } \\
\text { ents while } 12 \\
\text { also }\end{array}$ & $\begin{array}{l}\text { nance of } \\
\text { ation and } \\
\text { anization } \\
\text { and also } \\
\text { findings } \\
\text { hagement } \\
\text { ies are } \\
\text { ates the } \\
\text { strongly } \\
\% \text { among } \\
\text { agree }\end{array}$ \\
\hline
\end{tabular}

4.3. Finding out the Relationship between staff
competency and procurement performance
The relationship between staffs competences and procurement performance in public institutionwas established through multiple regression analysis and presented in the table 4.8 and 4.7. 
Table 4.7model summary

\begin{tabular}{ll}
\hline Multiple R & .350 \\
R Square & .059 \\
Adjusted R Square & .059 \\
Std. Error of the Estimate & .100 \\
Log-likelihood Function Value & 53.449 \\
\hline
\end{tabular}

As indicated in Table 4.7, the relationship between staff competence and procurement performance in public institution had a coefficient of 0.350 with a $\mathrm{R}$ square of 0.059 . The relationship was positive Table 4.1 Regression Analysis. Coefficients

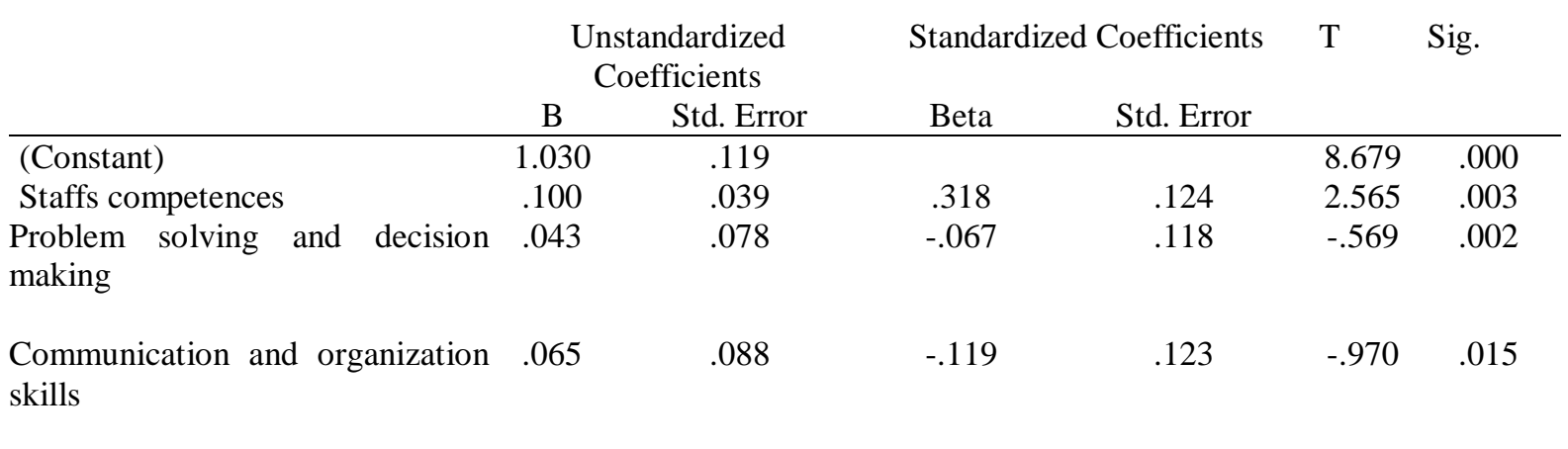

The intercept of the regression was 1.030 and statistically significant $\mathrm{p}=0.000)$. While the coefficient of staffs competences which is 0.100 and $\mathrm{p}=0.003$. procurement performance had an intercept of 0.044 but significant and finally communication and organization skills had it at 0.065 and also positive.The findings justify the model relationship below : $y=\beta_{1} x_{1}+\beta_{2} x_{2}+\beta_{3} x_{3}+\varepsilon$

\section{Discussion}

Results evidenced mutual agreements concur with the study of Mbae (2014) and (Mauki, 2014). In this study the significant impact of Staff competence on public procurement performance evaluated throughout education level, procurement knowledge specialization, professional experience and skills. The present study revealed that RPPA maintain skilled staffs who are more competent in achieving the core performance. This was strongly agreed by $84.2 \%$ of respondents while $83.2 \%$ of respondents also agreed.

This study did not contrast the findings of (Banda 2009) who conducted a research on staff competency and noted that many procuring organizations lack competent staff to executed procurement processes.For the institution to acquire productivity or procurement performance, the institution has to implying improvement in staff competence which contribute to the procurement performance in public institutionin Rwanda. $=.200^{*}, \mathrm{p}=.048$ ).
Where $\mathrm{y}$ is,staffs competences and constants, $\beta_{1,2,3,4} x_{1,2,3,4}$

are constants and variables (problem solving, decision making and communication and organization skills respectively). Substituting the coefficients, the model therefore is modified as; procurement performance 0.1 (problem solving) +0.043 (decision making) +0.065 (communication and organization skills) +1.03

engage in staff training. Qualified procurement staff follow procurement procedures and all work is executed well (Appiah, 2010). This study was also supported by the idea of Banda (2009) who concluded that solving a problem consists of having analytical skills by institution workers in different department to get things right in terms duties and responsibilities.

This study did not contradict the findings of Russell (2004), who argued that having clear and efficiency of procurement strategy, staff training would be crucial to enables the procurement staff acquire skills regarding procurement procedure. Efficiency and effectiveness of decision making by the management of RPPA has led to procurement performance as indicated by $57.9 \%$ of respondents and this has also agreed by $36.8 \%$ of surveyed respondents. 
The study concurs with the findings of Sheffi\& Klaus (2002)who said that poor communication system, poor management in procurement is due to limited skills relevant in procurement management. Carr\& Smeltzer (2000) and Peterson \& Van (2004) treated skills as the ability to execute some specific behavioral task in an organization. For procurement to be strategic, procurement professionals need to have skills related communication, management and competencies.

\section{Conclusions}

To the first objective, the study concludes that the impact of staff competence om procurement performance at RPPA maintained skilled staffs who are more competent in achieving the core performance. This was strongly agreed by $84.2 \%$ of respondents while $83.2 \%$ of respondents also agreed.

To the second objective, the study maintaining skilled and experienced staff has assisted the management to solve problem as strongly agreed by $33.7 \%$ of surveyed respondents. And $63.2 \%$ of respondents who also agreed. As indicated by $67.4 \%$ of respondents strongly agreed that the institution offers additional skills to staff members and this has led to procurement performance. This also was supported by $37.6 \%$ of surveyed respondents.

\section{Acknowledgments}

I wish to acknowledge Dr.Ernest Safari for his contribution to this work from the beginning up to its completion. I also wish to extend my

\section{Reference}

[1] Carr, A. \& Smeltzer. L. (2000), An Empirical study of the Relationship among purchasing skills and strategic purchasing, financial performance, and supplier responsiveness. Challenges and Improvement opportunities. Public Administration Research, 2(2)

[2] Gul, H. (2010). Modernizing public procurement and creating an independent public Procurement regulatory authority. Law transition online.

[3] Jeppesen, R. (2010). Accountability in public procurement transparency and the role of civil society. United Nations Procurement Capacity Development Centre.

[4] Agaba, E. \& Shipman, N. (2007). Public Procurement Reforms in Developing Countries:

[5] The Ugandan Experience. In G. Piga, \& K. V. Thai (Eds.), Advancing Public
Therefore, previous studies and evidences had evidenced that thelink between staff competence and procurement performance, the staff competence need to be more effective and efficiency to reflect the performance of procurement. Therefore, this assists institutions towards costs effectiveness which leads to institution's profit margin. This is also influenced by suppliers for products or service, quality improvement and most procurement performance is normally influenced by extent of competitive advantage (Vav, 2006).

To the third objective, the study found out information collected from $80.0 \%$ of research participants strongly confirmed that effective communication among staff members of RPPA present the significant role on procurement performance.as agreed by $20.0 \%$ of surveyed respondents. However, having both technical, interpersonal communication as well as organization skills assisted RPPA to achieve the procurement performance as indicated by $71.6 \%$ who strongly agreed whereas $34.7 \%$ also agreed.

As indicated by research participants, having good management structure, good organization skills were also important in achieving the procurement performance at RPPA as strongly confirmed by $60.0 \%$ and also $35.8 \%$ agreed.

acknowledgement to the Mount Kenya University, Rwanda Public Procurement Authority for their support and collaboration during the data collection

Procurement: Practices, Innovation and Knowledge Sharing.

[6] Basheka, B. C. (2013). The Science of Public Procurement and Administration. International PublicProcurement Conference (IPPC), 20-330.

[7] Keeney, S. (2007). The Foundations of Government Contracting. Journal of Contract Management.

[8] Basheka, B. C., \&Kabatereine, D. (2013). Public Procurement Reforms in Uganda. A Historical Trajectory. Journal of Public Procurement and Contract Management.

[9] Siri, G. (2005). Procurement Professionals and Ethics: A Little History (pp. 1-2). NCMA Tri Valley Chapter Times

[10] Thai, K. V. (2001). Public Procurement Reexamined. Journal of Public Procurement, 1(1), 9-50. United Nations Development Programme. (2007). Contract, Asset and Procurement Management User Guide. Retrieved from 
http://www.content.undp.org/go/userguide/c ap/procurement

[11] Mbae, L. (2014).Public Procurement Law and Procurement Performance of County Government in Kenya; Case of Machakos County Government. International Journal of Research in Management,Economics and Commerce, 2(2), 14-19.

[12] Muange, E. (2013). Procurement Legislation and Performance of Sub-County Fund Committees in Kenya. International Journal of Science and Research, 2(3), 19,22
[13] Nuxoll, E. M. (2006). United States at War: Understanding Conflict and Society. Secret Committee of Congress. ABC-CLIO. MidContinent Public Library, Kansas City.

[14] Van Weele, A. J. (2006). Purchasing \& Supply Chain Management: Analysis, Strategy, Planning and Practice, (4th Ed.). Australia: Thomson.

[15] Raymond, J. (2008). Benchmarking in public Procurement. Benchmarking: An International Journal, 15(6), 782793 